\title{
Recovery of Antioxidants from Grape Seeds and its Application in Fried Food
}

\section{Benjaruk Vayupharp* and Varaporn Laksanalamai}

Rangsit University, Phatumthani 12000, Thailand

\begin{abstract}
The efficiency of organic solvents and the conditions for extraction of phenolics from grape seeds was investigated. Two selected organic solvents; aqueous ethanol and acetone were studied at various concentrations between $0-100 \%$ and the extraction was performed either at room temperature or at $50^{\circ} \mathrm{C}$ for $3-12$ hours. Results indicated that at $50^{\circ} \mathrm{C}$ for 6 hours the best extraction yield of $14.9 \%$ was obtained with $50 \%(\mathrm{v} / \mathrm{v})$ ethanol. Under this condition, the extract consisted of 0.33 ( $/$ / g grape seed) total phenol. The $\mathrm{EC}_{50}$ measured by the 2,2-diphenyl1-picrylhydrazyl (DPPH) method and reducing power were $214.6 \mu \mathrm{g} / \mathrm{ml}$ and 2.38 respectively, which implied a high antioxidant activity of the extract. When considering the cost of operation and the safety concerns associated with solvent residue in the product, aqueous ethanol $(50 \%, \mathrm{v} / \mathrm{v})$ was an appropriate solvent comparing to aqueous acetone at various concentrations. Also, the effect of the extract on retarding oxidative rancidity of fried pork products was compared with 2 commercial additives; butylated hydroxytoluene (BHT) and gallic acid. At the concentration of 1.6 ( $\mathrm{g} / \mathrm{kg}$ product) the extract was similar in retarding rancidity efficiency to BHT but lower than gallic acid.
\end{abstract}

Keywords: Antioxidant; Grape Seed Extracts (GSEs); Total phenol

\section{Introduction}

The lipid oxidation is one of the major problems in meat industries. Meat products that are constituted of lipid and polyunsaturated fatty acids (PUFAs) tend to deteriorate due to lipid oxidation, leading to development of unpleasant flavors during processing and storage. The development of rancidity rapidly occurred especially when the products are exposed to air and cooked in frying oil [1,2]. In addition to the undesirable quality, the adverse effect of lipid oxidation leads to the development of free radicals which are involved in diseases and a range of disorders including cancer, arthritis, atherosclerosis, Alzheimer's disease, and diabetes. The supplement of synthetic antioxidants is a method of inhibiting lipid oxidation in meat products. However, synthetic antioxidants such as butylated hydoxyanisole (BHA) and butylated hydroxytolune (BHT) have restricted use in foods as these agents are known to be carcinogenic [3].

The medicinal and nutritional value of grapes (Vitis vinifera) has been heralded for thousands of years. Among other beneficial effects of parts of a grape, grape seeds are believed to have a powerful antioxidant property due to its rich source of polyphenol compounds. The polyphenol compounds are as much as 60-7 $0 \%$ in grape seeds compared only $10 \%$ in the fruit and $28-35 \%$ in the peels [4,5]. Most of the polyphenol compounds found in grape seeds are flavonoids, monometric, flavan-3ols, catechin and epicatechin as shown in Figure 1. These compounds are of interest in pharmaceutical and food factories for medical treatments and health supplements [4].

It is likely that the demand for using natural antioxidants such as GSEs has greatly increased in recent years. GSEs are substantially constituted with proanthocyanidins. They can react with free radicals and catalyzed metal ions necessary for the oxidation reaction then terminate chain reactions by removing radical intermediates, and inhibit other oxidation reactions by being oxidized themselves [2,6]. It is also reported that GSEs have been associated with other antioxidants to accelerate the prevention of oxidation reactions [7]. The GSEs were used for inhibition of rancidity in cooked beef [8]. There was a report on the supplement of GSE concentrations of $10 \mathrm{~g}$ and $20 \mathrm{~g} / \mathrm{kg}$ of turkey patties could reduce the thiobarbituric acid reactive substances (TBARS) 10 times compared to the product without supplement [9]. The effectiveness of GSEs on the prevention of lipid oxidation

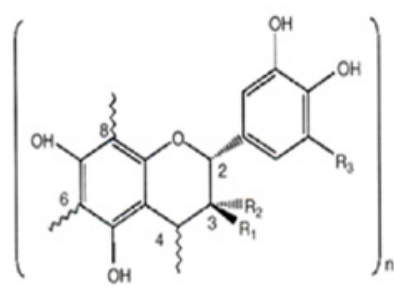

(a)

(b)<smiles>O=C(O)c1cc(O)c(O)c(O)c1</smiles>

Figure 1: (a) Grape proanthocyanidins: $n$, degree of polymerization. At the $\mathrm{C}_{4}-\mathrm{C}_{6}$ or $\mathrm{C}_{4}-\mathrm{C}_{8}$, the linkage of another molecule : (+)-catechin, $\left(\mathrm{R}_{1}=\mathrm{OH}, \mathrm{R}_{2}=\right.$ $\left.H_{1}, R_{3}=H\right):(-)$-epicatechin, $\left(R_{1}=H, R_{2}=O H, R_{3}=H\right):(-)$ Epicatechin-3-o-gallate $\left(R_{1}=H, R_{2}=\right.$-galloyl, $\left.R_{3}=H\right)$ : (-)-Epigallocatechin: $\left(R_{1}=H, R_{2}=O H, R_{3}=O H\right)(b)$ The molecular structure of Gallic acid [4]

*Corresponding author: Benjaruk Vayupharp, Faculty of Biotechnology, Rangsit University, Phatumthani 12000 Thailand; Fax: +2997-2220 ext 3661; E-mail: vbenjaruk@yahoo.com

Received March 12, 2012; Accepted April 05, 2012; Published April 09, 2012

Citation: Vayupharp B, Laksanalamai $\vee$ (2012) Recovery of Antioxidants from Grape Seeds and its Application in Fried Food. J Food Process Technol 3:152. doi:10.4172/2157-7110.1000152

Copyright: ๑ 2012 Vayupharp B, et al. This is an open-access article distributed under the terms of the Creative Commons Attribution License, which permits unrestricted use, distribution, and reproduction in any medium, provided the original author and source are credited. 
was increased at the lower temperature and under vacuum packing conditions [1].

In Thailand, there is a report from one wine factory that approximately 2,500 tons of grapes are used for winery processing which discarded 125 tons of grape seeds as waste annually (data from Siam Vinery Factory). The factory faces a dilemma in disposing the waste seeds. In general practice, these seeds are piled causing problems with space and spoilage in the factory. Although numerous methods of extraction have been developed with higher yields and lower costs there are a few study interests in extraction of polyphenol compounds from grape seeds obtained from the wine factory in Thailand.

The objective of the research has been to search for the appropriate organic solvents such as ethanol, and acetone for the extraction of grape seeds from the Thai wine factory. Research has focused towards high yields and low costs with the safety concerns. The application of the GSE on the fried pork products has been further studied for determining its antioxidant property compared to synthetic antioxidants.

\section{Materials and Methods}

\section{Grape seed preparation}

Grape seeds, byproduct of Pok Dum grapes (Vitis vinifera L.) were obtained from the winery factory. The seeds were washed with distilled water and cleaned then dried at $60^{\circ} \mathrm{C}$ for 12 hours or until the moisture content reached the lowest amount of $2.5 \%$ to prevent water interfering during extraction. Samples were ground to 850 mesh and kept in a closed container. When used, the grape seeds were soaked in the hexane solution over-night then the mixture was filtered and the hexane was evaporated. The defatted grape seed was extracted as mentioned in the subsequent procedure.

\section{The extraction procedure}

The $10 \mathrm{~g}$ - ground sample was extracted for 24 hours with $100 \mathrm{~mL}$ containing three extractants; aqueous ethanol (ethanol concentration of $20,50,80$, and $100 \%, \mathrm{v} / \mathrm{v}$ ), aqueous acetone (acetone concentration of $20,50,80$, and $100 \%, \mathrm{v} / \mathrm{v}$ ), and pure water in a rotary shaker (Gerhardt, RO 30, Germany) at $100 \mathrm{rpm}$ at room temperature. After extraction, the sample was centrifuged for 15 minutes at $4^{\circ} \mathrm{C}$ and 8,000 g. The extract then was freeze dried $\left(-58^{\circ} \mathrm{C}, 0.005 \mathrm{psi}\right)$ and kept for further analysis.

The dried extract was determined for the total phenol and the antioxidant activity by the DPPH radical scavenging assay [10] and reducing power [11]. These properties were statistically analyzed as the indicators of choosing the appropriate extractant in the next experiment.

The ground seeds were added with the selected extractant and extracted at room temperature and at $50^{\circ} \mathrm{C}$ for $3-12$ hours. The properties of the extract were determined according to the methods mentioned below.

\section{Determination of total phenolic contents}

The total phenolic contents of GSE were determined spectrophotometrically according to Folin-Ciocalteu colorimetric method and absorbances at $740 \mathrm{~nm}$ using gallic acid as a standard [10].

\section{Determination of radical scavenging activity}

$$
\text { 2,2-Diphenyl-1-picrylhydrazyl (DPPH): Free radical }
$$

2,2-diphenyl-1-picrylhydrazyl (DPPH), from Sigma Aldrich Ltd., England and GSE were dissolved in ethanol. The solutions $(0.5 \mathrm{ml})$ were mixed with DPPH solution $(3.5 \mathrm{ml})$, covered and left in the dark at room temperature. Samples with $0.5 \mathrm{ml}$ ethanol instead of GSE were used as blank. After $180 \mathrm{~min}$ of incubation, the reduction of the DPPH free radical was measured by reading the absorbance at 515 nm using a UV-vis spectrophotometer (model Biochrom Libra S22). The percentage of remaining DPPH at steady state was plotted against the sample concentration to obtain the amount of sample required to decrease the initial DPPH concentration by $50 \%\left(\mathrm{EC}_{50}\right)$. Antioxidant activity was calculated as the reciprocal of $\mathrm{EC}_{50}$, the antiradical power (ARP) in units of grams of DPPH / g of tablet [1].

Reducing power: GSEs in $1 \mathrm{ml}$ methanol were mixed with 2.5 $\mathrm{ml}$ of phosphate buffer $(0.2 \mathrm{M}, \mathrm{pH} 6.6)$ and $2.5 \mathrm{ml}$ of $1 \%$ potassium ferricyanide in $10-\mathrm{ml}$ test tubes. The mixtures were incubated for 20 min at $50^{\circ} \mathrm{C}$. At the end of the incubation, $2.5 \mathrm{ml}$ of $10 \%$ trichloroacetic was added to the mixtures, followed by centrifuging at $5000 \mathrm{rpm}$ for $10 \mathrm{~min}$. The upper layer $(2.5 \mathrm{ml})$ was mixed with $2.5 \mathrm{ml}$ of distilled water and $0.5 \mathrm{ml}$ of $0.1 \%$ ferric chloride. The absorbance was measured at $700 \mathrm{~nm}$ using a UV-vis spectrophotometer (model Biochrom Libra S22) [11].

Use of GSE for inhibition of the rancidity comparing to commercial antioxidants in fried pork product: The seed extract was added to the fried pork at concentrations from 0.1 to $1.6 \mathrm{~g} / \mathrm{kg}$ comparing to two synthetic antioxidants, namely, the butylated hydroxytoluene (BHT) and gallic acid of $0.1 \mathrm{~g} / \mathrm{kg}$. The products were kept in polyethylene bags and stored at $10^{\circ} \mathrm{C}$, room temperature, and $60^{\circ} \mathrm{C}$ for 15 days. The products were sampled every 2 days to determine the rancidity by measuring the TBA value $[12,13]$ and the peroxide value (PV) [14].

\section{Statistical analysis}

The completed randomized experimental design (CRD) was applied to the research. The factors were extractants, concentrations and temperatures. Analysis of the variance was done and all tests were considered statistical significance $(\mathrm{p}<0.05)$. Comparing means was examined by the Duncan's Multiple Range Test (DMRT) at the significance level of 0.05 .

\section{Results and Discussion}

\section{Determination of appropriate solvents for extraction of poly phenol from grape seeds}

The pure extractants such as water, acetone, and ethanol for extraction of grape seeds gave the extract yields of $7.51 \%, 4.65 \%$, and $10.55 \%$ respectively, while using the mixture of ethanol or acetone with water for extraction the extract yield was between 10-16\%.

Although water posses a high dielectric constant of 80 it will dissolve proteins, polysaccharides and other polar substances with the results of decreasing purity of the extracts. In addition, a high DPPH and low reducing power of the GSE prepared by water was obtained which implied a low antioxidant activity of the extract. Results confirmed that water was considered not an appropriate solvent for extraction comparing to pure acetone and ethanol.

Our results showed that ethanol gave yield of $10.55 \%$, higher than yield of pure acetone $4.65 \%$. Percent yield extraction depended on types 
Citation: Vayupharp B, Laksanalamai V (2012) Recovery of Antioxidants from Grape Seeds and its Application in Fried Food. J Food Process Technol 3:152. doi:10.4172/2157-7110.1000152

Page 3 of 6

of components in grape seeds and polarity of solvent. Ethanol had a higher capability of extraction polar compounds than pure acetone. The dielectric constant values of ethanol and acetone equaled to 24 and 22, respectively, but these values were reported higher when diluted [15]. Results also showed that when $20 \%$ of water was added to acetone the extraction yield was significantly improved from $4.65 \%$ to $16.56 \%$. This could be explained by the increase polarity of an aqueous mixture of acetone for extraction more polar compounds in grape seeds. However, further in water content from 20 to $50-80 \%$ in the extraction system, the extraction for some non polar compounds which was always dissolved in $80 \%$ acetone may not be extracted due to the increase polarity of acetone approaching to polarity of water. The extraction yield therefore was decreased. This result was in agreement with other authors that the mixture of water and acetone $(20: 80)$ solution was the best extractant for polyphenol compounds [16].

When water was added from $20 \%$ to $80 \%$ to ethanol, the polarity of ethanol slightly changed due the high polarity of ethanol, the most polar compounds were then extracted in the aqueous mixture of $20 \%$ ethanol therefore, and the extraction yield was not much affected. However, the extraction yield exhibited low DPPH and high reducing power similarly to that extracted by the acetone solution.

Considering the safety and toxic residue after extraction, ethanol was preferred to acetone for extraction. The extraction yield by ethanol at the concentration of $50 \%$ was not significantly different from that of $80 \%$. The data presented here (Table 1) thus indicated that ethanol at a concentration of $50 \%$ was the appropriate solvent for extraction of polyphenol from grape seeds in terms of economics and safety concerns.

\section{Determination of appropriate quantity of grape seeds, extraction time and temperature}

The ratio of grape seeds and solvent had affected the extraction yield at the extraction time of 3-12 hours using $50 \%$ ethanol and at room temperature as shown in Table 2. The selected temperature for extraction was recommended not to exceed $50^{\circ} \mathrm{C}$ [17], to prevent the evaporation of ethanol (the boiling point of ethanol was $78.5^{\circ} \mathrm{C}$ ). The longer extraction time, however decreased the total phenolics extracted, and caused the oxidation reaction with the consequence of degrading the polyphenol substances. In addition, unexpected substances such as proteins and polysaccharides were obtained which interfered to the purity of the product [17].

Results found that there was no significant difference $(p \geq 0.05)$ in the extraction yield when grape seeds of $10 \mathrm{~g} / 100 \mathrm{ml}$ were employed for the extraction time of 3-12 hours at room temperature. The extraction yield was approximately $10-11 \%$. The extracts were determined for the antioxidant property by measuring the $\mathrm{EC}_{50}$ value, the higher the $\mathrm{EC}_{50}$ the lower the antioxidant power. When the extraction time increased to 12 hours, the $\mathrm{EC}_{50}$ value significantly increased to $275.33 \mu / \mathrm{ml}$, regarding to the oxidation reaction and degradation of polyphenols as mentioned above. Thus the lower ability in scavenging effect of the extracts was observed under the extended extraction time.

When comparing the amount of grape seeds at the extraction

\begin{tabular}{|c|c|c|c|c|}
\hline Type of solvent $(\% \mathrm{v} / \mathrm{v})$ & $\begin{array}{l}\text { DPPH } \\
\left(E_{50}\right)\end{array}$ & $\begin{array}{l}\text { Reducing power } \\
\left(O D_{700}\right)\end{array}$ & $\begin{array}{c}\text { Total phenol } \\
\text { (g/g grape seed extracts) }\end{array}$ & Yield (\%) \\
\hline Water, 100 & $520.00^{h} \pm 2.33$ & $0.6737^{9} \pm 0.0020$ & $0.1054^{\mathrm{h}} \pm 0.0030$ & $7.51^{\mathrm{e}} \pm 0.07$ \\
\hline Water :ethanol, 80:20 & $353.33^{\mathrm{e}} \pm 1.81$ & $1.0813^{c} \pm 0.0251$ & $0.2126^{d} \pm 0.0039$ & $10.95^{\mathrm{cd}} \pm 0.33$ \\
\hline Water :ethanol,50:50 & $255.33^{c} \pm 5.02$ & $1.1917^{a} \pm 0.0155$ & $0.2200^{\circ} \pm 0.0038$ & $11.25^{c} \pm 0.21$ \\
\hline Water :ethanol, 20:80 & $251.33^{c} \pm 3.07$ & $1.1650^{\mathrm{b}} \pm 0.0169$ & $0.2186^{c} \pm 0.0040$ & $11.18^{c} \pm 0.19$ \\
\hline Ethanol,100 & $303.33^{d} \pm 5.35$ & $0.8000^{\mathrm{e}} \pm 0.0074$ & $0.1566^{f} \pm 0.0032$ & $10.55^{\mathrm{cd}} \pm 0.01$ \\
\hline Water :acetone, 80:20 & $394.33^{9} \pm 2.64$ & $1.0643^{c} \pm 0.0089$ & $0.2060^{e} \pm 0.0018$ & $10.28^{d} \pm 0.16$ \\
\hline Water :acetone, 50: 50 & $242.67^{b} \pm 3.28$ & $1.1697^{\mathrm{b}} \pm 0.0180$ & $0.2280^{b} \pm 0.0012$ & $15.37^{b} \pm 0.75$ \\
\hline Water :acetone, 20: 80 & $210.67^{a} \pm 1.42$ & $1.2043^{a} \pm 0.0193$ & $0.2380^{\mathrm{a}} \pm 0.0007$ & $16.51^{a} \pm 0.55$ \\
\hline Acetone100 & $374.67^{f} \pm 4.79$ & $0.7057^{f} \pm 0.0152$ & $0.1526^{9} \pm 0.0043$ & $4.65^{f} \pm 0.73$ \\
\hline
\end{tabular}

Different letters indicated significant differences $(P<0.05)$ for values of one property down the column Values were means \pm SE (with 3 replications)

Table 1: The properties and yield of GSE using various concentrations of solvents.

\begin{tabular}{|c|c|c|c|c|}
\hline Extraction conditions & $\begin{array}{c}\mathrm{EC}_{50} \\
(\mu \mathrm{g} / \mathrm{ml})\end{array}$ & $\begin{array}{l}\text { Reducing power } \\
\left(O D_{700}\right)\end{array}$ & $\begin{array}{c}\text { Total phenol } \\
\text { (g/g grape seed extracts) }\end{array}$ & Yield (\%) \\
\hline $5 \mathrm{~g}$ grape seeds, $3 \mathrm{hr}$. & $290.67^{g} \pm 3.30$ & $1.8776^{d} \pm 0.0446$ & $0.1980^{\mathrm{e}} \pm 0.0012$ & $13.07^{\mathrm{ab}} \pm 1.34$ \\
\hline $7.5 \mathrm{~g}$ grape seed, $3 \mathrm{hr}$. & $270.47^{b} \pm 2.95$ & $2.0193^{\mathrm{cd}} \pm 0.0252$ & $0.2226^{\mathrm{d}} \pm 0.0011$ & $10.86^{\mathrm{cd}} \pm 0.13$ \\
\hline $10 \mathrm{~g}$ grape seed, $3 \mathrm{hr}$. & $261.33^{\mathrm{a}} \pm 4.86$ & $2.1306^{b c} \pm 0.0303$ & $0.2360^{\mathrm{cd}} \pm 0.0010$ & $11.78^{\mathrm{bcd}} \pm 0.16$ \\
\hline $5 \mathrm{~g}$ grape seed, $6 \mathrm{hr}$. & $276.67^{c} \pm 2.29$ & $1.9023^{d} \pm 0.0216$ & $0.2013^{e} \pm 0.0024$ & $13.72^{\mathrm{a}} \pm 0.24$ \\
\hline 7. g grape seed, $6 \mathrm{hr}$. & $282.00^{\mathrm{de}} \pm 2.31$ & $2.0360^{\text {cd }} \pm 0.0674$ & $0.2246^{d} \pm 0.0084$ & $12.87^{\mathrm{ab}} \pm 0.31$ \\
\hline $10 \mathrm{~g}$ grape seed, $6 \mathrm{hr}$. & $260.00^{\mathrm{a}} \pm 3.86$ & $2.2283^{\mathrm{a}} \pm 0.0325$ & $0.2633^{a} \pm 0.0014$ & $11.73^{\mathrm{bcd}} \pm 0.07$ \\
\hline $5 \mathrm{~g}$ grape seed, $9 \mathrm{hr}$. & $287.33^{\mathrm{fg}} \pm 4.20$ & $2.0297^{\mathrm{cd}} \pm 0.0234$ & $0.2013^{e} \pm 0.0007$ & $13.55^{\mathrm{a}} \pm 0.36$ \\
\hline $7.5 \mathrm{~g}$ grape seed, $9 \mathrm{hr}$. & $278.00^{c} \pm 2.75$ & $2.0043^{e} \pm 0.0315$ & $0.2487^{a b} \pm 0.0046$ & $12.28^{\mathrm{abc}} \pm 1.51$ \\
\hline $10 \mathrm{~g}$ grape seed, $9 \mathrm{hr}$. & $259.33^{\mathrm{a}} \pm 4.56$ & $2.2248^{a} \pm 0.0040$ & $0.2621^{a} \pm 0.0133$ & $11.89^{\mathrm{bcd}} \pm 0.16$ \\
\hline $5 \mathrm{~g}$ grape seed, $12 \mathrm{hr}$. & $285.33^{\text {ef }} \pm 3.87$ & $2.0127^{c d} \pm 0.0415$ & $0.2040^{\mathrm{e}} \pm 0.0027$ & $13.24^{\mathrm{ab}} \pm 0.09$ \\
\hline $7.5 \mathrm{~g}$ grape seed, $12 \mathrm{hr}$. & $278.67^{\mathrm{cd}} \pm 1.95$ & $2.1983^{a b} \pm 0.0136$ & $0.2460^{\mathrm{ab}} \pm 0.0043$ & $10.99^{\mathrm{cd}} \pm 0.20$ \\
\hline $10 \mathrm{~g}$ grape seed, $12 \mathrm{hr}$. & $275.33^{c} \pm 0.61$ & $2.0893^{c} \pm 0.0275$ & $0.2580^{\mathrm{ab}} \pm 0.0047$ & $10.39^{d} \pm 0.10$ \\
\hline
\end{tabular}

Different letters indicate significant differences $(P<0.05)$ for values of one property down the column

Values are means \pm SE (with 3 replications)

Table 2: The properties and yield of GSE using 50\% ethanol at room temperature, various amounts of grape seeds and extraction time. 
Citation: Vayupharp B, Laksanalamai V (2012) Recovery of Antioxidants from Grape Seeds and its Application in Fried Food. J Food Process Technol 3:152. doi:10.4172/2157-7110.1000152

Page 4 of 6

\begin{tabular}{|c|c|c|c|c|}
\hline Extraction conditions & $\begin{array}{c}E_{50} \\
(\mu \mathrm{g} / \mathrm{ml})\end{array}$ & $\begin{array}{l}\text { Reducing } \\
\left(O D_{700}\right)\end{array}$ & $\begin{array}{c}\text { Total phenol } \\
\text { (g/g grape seed extracts) }\end{array}$ & Yield (\%) \\
\hline $5 \mathrm{~g}$ grape seeds, $3 \mathrm{hr}$. & $286.67^{9} \pm 3.07$ & $1.6057^{e} \pm 0.0381$ & $0.2607^{i} \pm 0.0016$ & $14.44^{\mathrm{ab}} \pm 0.03$ \\
\hline $7.5 \mathrm{~g}$ grape seed, $3 \mathrm{hr}$. & $271.33^{e} \pm 1.76$ & $1.8877^{\mathrm{cd}} \pm 0.0174$ & $0.2660^{g} \pm 0.0003$ & $13.35^{\mathrm{de}} \pm 0.23$ \\
\hline $10 \mathrm{~g}$ grape seed, $3 \mathrm{hr}$. & $260.67^{\mathrm{cd}} \pm 4.21$ & $2.0307^{b} \pm 0.0043$ & $0.2680^{f} \pm 0.0006$ & $12.98^{\mathrm{ef}} \pm 0.30$ \\
\hline $5 \mathrm{~g}$ grape seed, $6 \mathrm{hr}$. & $274.67^{e} \pm 4.44$ & $1.8450^{d} \pm 0.1621$ & $0.2633^{\mathrm{h}} \pm 0.0001$ & $14.40^{\mathrm{abc}} \pm 0.13$ \\
\hline $7.5 \mathrm{~g}$ grape seed, $6 \mathrm{hr}$. & $214.60^{\mathrm{a}} \pm 1.64$ & $2.3847^{a} \pm 0.0229$ & $0.3286^{\mathrm{a}} \pm 0.0004$ & $14.86^{a} \pm 0.03$ \\
\hline $10 \mathrm{~g}$ grape seed, $6 \mathrm{hr}$. & $252.67^{b} \pm 1.56$ & $2.3027^{a} \pm 0.0572$ & $0.2993^{b} \pm 0.0004$ & $12.67^{\mathrm{fg}} \pm 0.25$ \\
\hline $5 \mathrm{~g}$ grape seed, $9 \mathrm{hr}$. & $285.33^{\mathrm{fg}} \pm 4.84$ & $1.7780^{\mathrm{d}} \pm 0.0144$ & $0.2673^{\mathrm{fg}} \pm 0.0007$ & $14.16^{\mathrm{bc}} \pm 0.17$ \\
\hline $7.5 \mathrm{~g}$ grape seed, $9 \mathrm{hr}$. & $274.00^{e} \pm 3.01$ & $1.8437^{d} \pm 0.0230$ & $0.2626^{\mathrm{h}} \pm 0.0010$ & $14.54^{\mathrm{ab}} \pm 0.79$ \\
\hline $10 \mathrm{~g}$ grape seed, $9 \mathrm{hr}$. & $258.67^{c} \pm 3.01$ & $2.3573^{a} \pm 0.0218$ & $0.2813^{\mathrm{c}} \pm 0.0013$ & $12.98^{\mathrm{ef}} \pm 0.29$ \\
\hline $5 \mathrm{~g}$ grape seed, $12 \mathrm{hr}$. & $282.00^{f} \pm 4.34$ & $2.0178^{b} \pm 0.0317$ & $0.2586^{j} \pm 0.0002$ & $14.81^{\mathrm{ab}} \pm 0.06$ \\
\hline $7.5 \mathrm{~g}$ grape seed, $12 \mathrm{hr}$. & $274.67^{e} \pm 4.82$ & $1.9917^{\mathrm{bc}} \pm 0.0304$ & $0.2726^{\mathrm{e}} \pm 0.0007$ & $13.75^{\mathrm{cd}} \pm 0.08$ \\
\hline $10 \mathrm{~g}$ grape seed, $12 \mathrm{hr}$. & $263.00^{d} \pm 1.51$ & $2.1220^{\mathrm{b}} \pm 0.0395$ & $0.2754^{d} \pm 0.0007$ & $12.20^{9} \pm 0.05$ \\
\hline
\end{tabular}

Different letters indicate significant differences $(P<0.05)$ for values of one property down the column

Values are means \pm SE (with 3 replications)

Table 3: The properties and yield of GSE using $50 \%$ ethanol at $50^{\circ} \mathrm{C}$, various amounts of grape seeds and extraction time.

\begin{tabular}{|l|c|c|c|}
\hline \multicolumn{1}{|c|}{ Extraction conditions } & $\begin{array}{c}\mathrm{EC}_{50} \\
(\boldsymbol{\mu g} / \mathbf{m l})\end{array}$ & $\begin{array}{c}\text { Reducing power } \\
\left(\mathbf{O D}_{\mathbf{7 0 0}}\right)\end{array}$ & $\begin{array}{c}\text { Total phenol } \\
\text { (g/g grape seed extracts) }\end{array}$ \\
\hline $10 \mathrm{~g}$ grape seed, 3 hours, room temperature & $261.33^{\mathrm{b}} \pm 4.86$ & $2.1306^{\mathrm{b}} \pm 0.0303$ & $0.2360^{\mathrm{b}} \pm 0.0010$ \\
\hline 7.5 g grape seed, 6 hours, $50^{\circ} \mathrm{C}$ & $214.60^{\mathrm{a}} \pm 1.64$ & $2.3847^{\mathrm{a}} \pm 0.0229$ & $11.78^{\mathrm{b}} \pm 0.16$ \\
\hline
\end{tabular}

Different letters indicate significant differences $(P<0.05)$ for values of one property down the column

Values are means \pm SE (with 3 replications)

Table 4: Comparison of properties and extraction yields of GSE using $50 \%$ ethanol at the selected extraction conditions.

time of 3 hours, results found that \% yield obtained from $5 \mathrm{~g}$ of grape seeds was the highest while those obtained from $10 \mathrm{~g}$ and $7.5 \mathrm{~g}$ was not significantly different. The reason could be explained by the increased ability of the solvent to contact a fewer amount of grape seeds. In addition, this could possibly dissolve other substances with a result of an increase in extracted yield. However, the total phenols of the extract obtained from 5-7.5 g grape seeds were less than that obtained from $10 \mathrm{~g}$ grape seeds due to other non reactive substances rather than polyphenol compounds in grape seeds were extracted. Therefore, when considering time and energy saving, the use of $10 \mathrm{~g}$ of grape seeds for 3 hour extraction at room temperature was chosen.

When the extraction temperature increased to $50^{\circ} \mathrm{C}$, it was found that using $7.5 \mathrm{~g}$ of grape seed for 6 hours extraction was the most efficient condition. By this condition, the highest \% GSE yield was

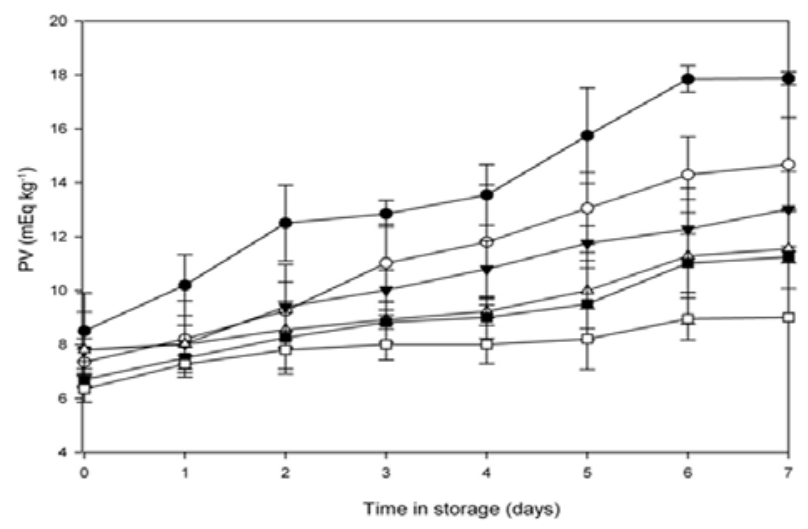

Figure 2: Changes in the peroxide value $(\mathrm{mEq} / \mathrm{Kg})$ in the fried pork over the time with the supplement with GSE $(0 \mathrm{~g} / \mathrm{kg} \bullet ; 0.4 \mathrm{~g} / \mathrm{kg} \circ ; 0.8 \mathrm{~g} / \mathrm{kg} \mathbf{\nabla} ; 1.6 \mathrm{~g} / \mathrm{kg} \Delta)$ and commercial antioxidants; (BHT $0.1 \mathrm{~g} / \mathrm{kg} \mathbf{m}$; Gallic acid $0.1 \mathrm{~g} / \mathrm{kg} \square$ ), stored at $10^{\circ} \mathrm{C}$. Bars indicate \pm SEtime with the supplement with GSE $(0 \mathrm{~g} / \mathrm{kg} \circ ; 0.4 \mathrm{~g} / \mathrm{kg}$ $\circ ; 0.8 \mathrm{~g} / \mathrm{kg} \mathbf{\nabla} ; 1.6 \mathrm{~g} / \mathrm{kg} \Delta$ ) and commercial antioxidants; (BHT $0.1 \mathrm{~g} / \mathrm{kg} \mathbf{m} ;$ Gallic acid $0.1 \mathrm{~g} / \mathrm{kg} \square)$, stored at $10^{\circ} \mathrm{C}$. Bars indicate $\pm \mathrm{SE}$.

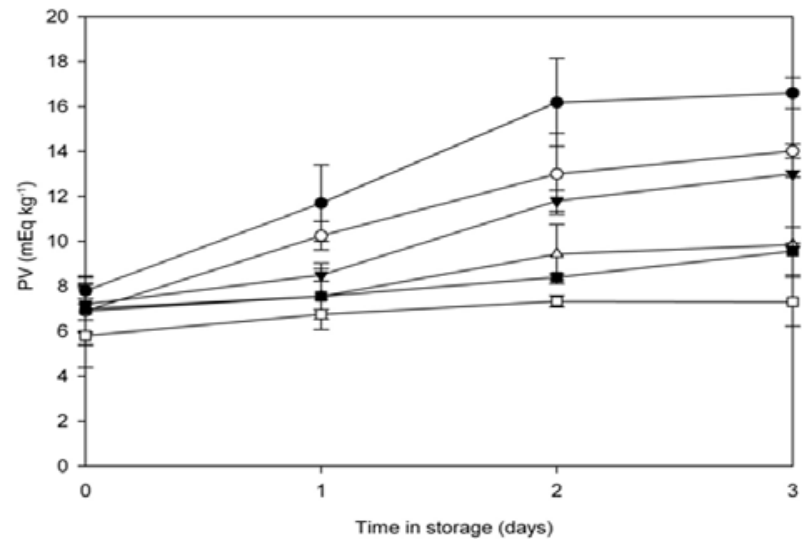

Figure 3: Changes in the peroxide value $(\mathrm{mEq} / \mathrm{Kg})$ in the fried pork over the time with the supplement with GSE $(0 \mathrm{~g} / \mathrm{kg} \bullet ; 0.4 \mathrm{~g} / \mathrm{kg} \circ ; 0.8 \mathrm{~g} / \mathrm{kg} \nabla ; 1.6 \mathrm{~g} / \mathrm{kg} \Delta)$ and commercial antioxidants; (BHT $0.1 \mathrm{~g} / \mathrm{kg} \mathbf{m} ;$ Gallic acid $0.1 \mathrm{~g} / \mathrm{kg} \square$ ), stored at room temperature. Bars indicate $\pm \mathrm{SE}$

obtained with the highest amount of total phenol, and reducing power value and lowest $\mathrm{EC}_{50}$ value. Such values were $14.86 \%, 0.3286,2.3847$, and 214.60 respectively in Table 3.

The increase in the temperature to $50^{\circ} \mathrm{C}$ improved the extraction yield compared to room temperature due to the softening of the grape seed tissue under the higher temperature. The high temperature also destroyed the covalent bonding between phenols and proteins and polysaccharides that caused easier contact between solvent and polyphenols [17]. Therefore it was concluded that most effective extraction condition was achieved by using $7.5 \mathrm{~g}$ of grape seeds at the $50^{\circ} \mathrm{C}$ for 6 hours to obtain the maximum yield with the highest antioxidant property in Table 4.

Use of GSEs for inhibiting rancidity in fried pork product 
Changes in the $\mathrm{PV}$ of fried pork product stored in various temperatures such as $10^{\circ} \mathrm{C}, 25^{\circ} \mathrm{C}$, and $60^{\circ} \mathrm{C}$ were shown in Figure 2-4. The sensitivity of the rancidity was determined by the PV which measured peroxides and hydroperoxides as caused by the reaction of lipid or oil with the oxygen. These peroxides were subsequently broken down to the smaller molecules of carbonyl compounds.

Results found that the PV of fried pork products stored at different temperatures dramatically increased when storage was lengthened. The $\mathrm{PV}$ of the fried pork product without supplement of the antioxidant was higher than the product with supplement GSEs and synthetic antioxidants.

The supplement of GSEs of 0.4-1.6 g / kg to the fried pork inhibited or delayed rancidity. There was no statistical difference in the rancidity as shown by the PV values in the fried pork added $1.6 \mathrm{~g} / \mathrm{kg}$ GSE and BHT. However, the gallic acid gave the most effective result in inhibiting rancidity in fried pork compared to other antioxidants.

It was noticed that molds grew on the fried pork when the product was kept for 4 days at room temperature. The PV of the contaminated product was increased to $16 \mathrm{mEq} / \mathrm{kg}$. The high PV was explained by

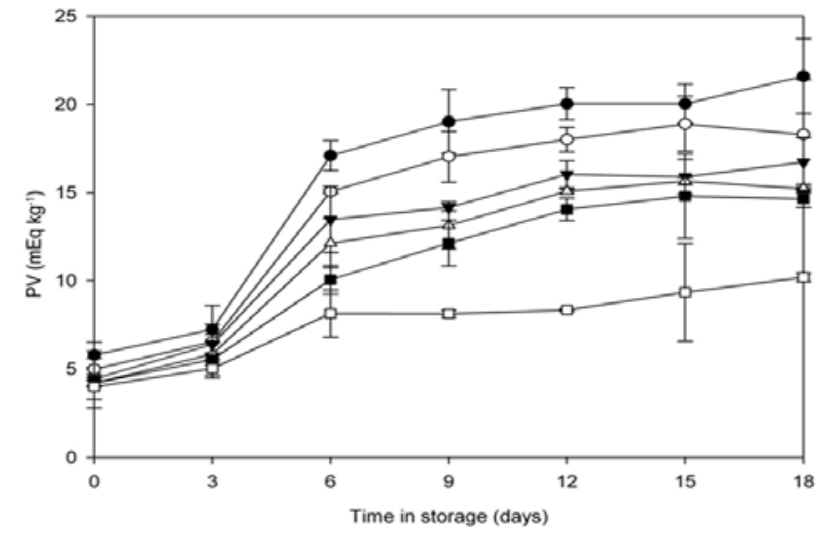

Figure 4: Changes in the peroxide value $(\mathrm{mEq} / \mathrm{Kg})$ in the fried pork over the time with the supplement with GSE $(0 \mathrm{~g} / \mathrm{kg} \bullet ; 0.4 \mathrm{~g} / \mathrm{kg} \circ ; 0.8 \mathrm{~g} / \mathrm{kg} \nabla ; 1.6 \mathrm{~g} / \mathrm{kg} \Delta)$ and commercial antioxidants; (BHT $0.1 \mathrm{~g} / \mathrm{kg}$ $;$; Gallic acid $0.1 \mathrm{~g} / \mathrm{kg} \square)$, stored at $60^{\circ} \mathrm{C}$ temperature. Bars indicate $\pm \mathrm{SE}$.

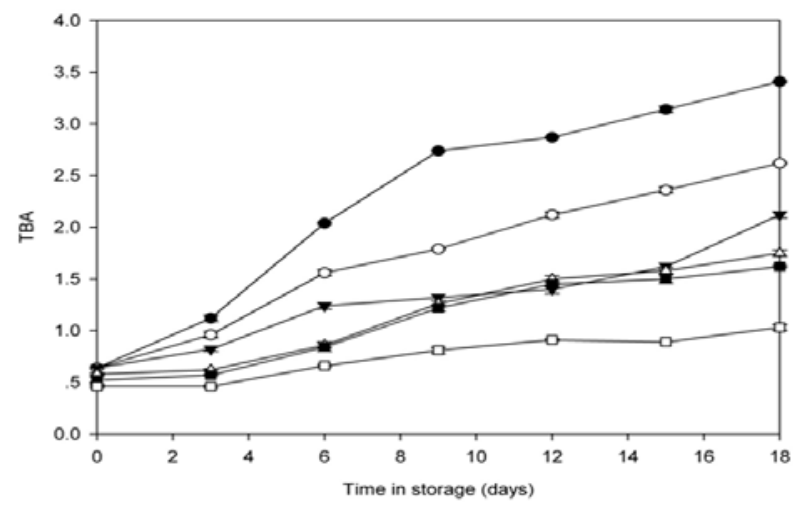

Figure 5: Changes in the Thiobarbituric acid (TBA) in the fried pork over the time with the supplement with GSE $(0 \mathrm{~g} / \mathrm{kg} \bullet ; 0.4 \mathrm{~g} / \mathrm{kg} \circ ; 0.8 \mathrm{~g} / \mathrm{kg} \nabla ; 1.6 \mathrm{~g} / \mathrm{kg} \Delta)$ and commercial antioxidants; (BHT $0.1 \mathrm{~g} / \mathrm{kg} \mathbf{~}$; Gallic acid $0.1 \mathrm{~g} / \mathrm{kg} \square$ ), stored at $10^{\circ} \mathrm{C}$ temperature. Bars indicate $\pm \mathrm{SE}$.

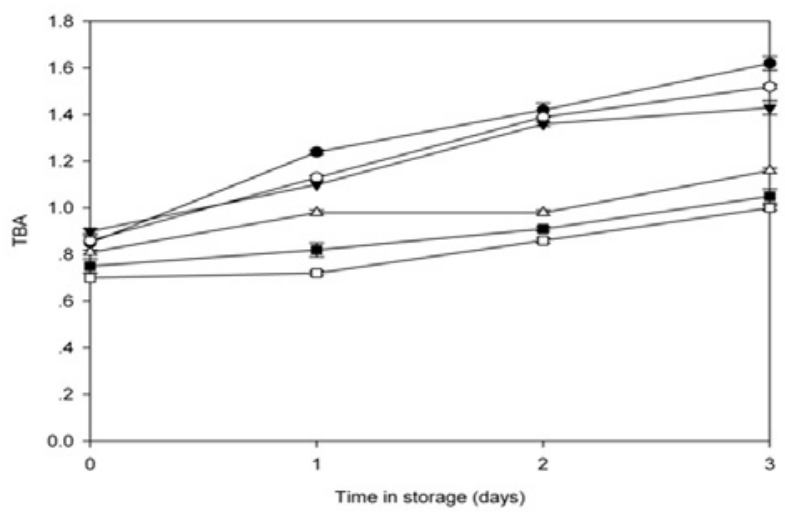

Figure 6: Changes in the Thiobarbituric acid (TBA) in the fried pork over the time with the supplement with GSE $(0 \mathrm{~g} / \mathrm{kg} \bullet ; 0.4 \mathrm{~g} / \mathrm{kg} \circ ; 0.8 \mathrm{~g} / \mathrm{kg} \boldsymbol{\nabla} ; 1.6 \mathrm{~g} / \mathrm{kg} \Delta)$ and commercial antioxidants; (BHT $0.1 \mathrm{~g} / \mathrm{kg}$; Gallic acid $0.1 \mathrm{~g} / \mathrm{kg} \square$ ), stored at room temperature. Bars indicate $\pm \mathrm{SE}$

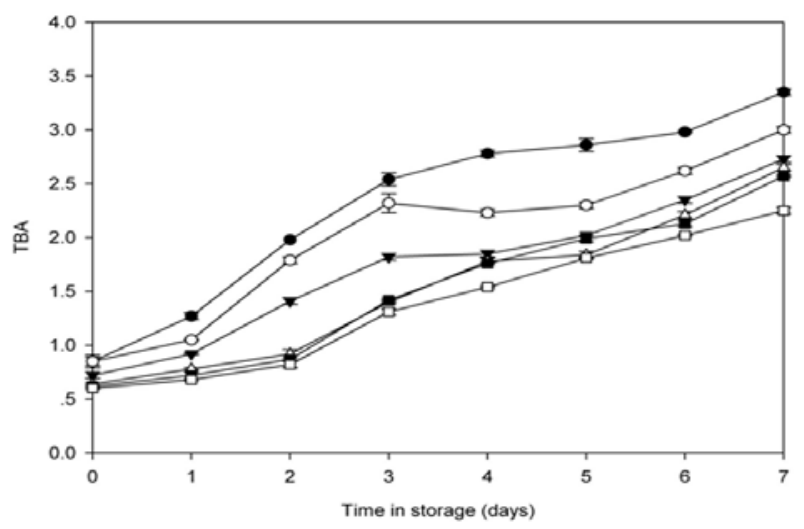

Figure 7: Changes in the Thiobarbituric acid (TBA) in the fried pork over the time with the supplement with GSE $(0 \mathrm{~g} / \mathrm{kg} \bullet ; 0.4 \mathrm{~g} / \mathrm{kg} \circ ; 0.8 \mathrm{~g} / \mathrm{kg} \nabla ; 1.6 \mathrm{~g} / \mathrm{kg} \Delta)$ and commercial antioxidants; (BHT $0.1 \mathrm{~g} / \mathrm{kg} \mathbf{m}$; Gallic acid $0.1 \mathrm{~g} / \mathrm{kg} \square$ ), stored at $60^{\circ} \mathrm{C}$. Bars indicate $\pm \mathrm{SE}$.

the oxidation rancidity in company with the hydrolytic rancidity in which the latter reaction was activated by lipase from the mold. These two reactions accelerated the rancidity of the product, thus increasing the PV (Figure 3). While kept the product at high temperature in the close container, the oxygen was lower than at room temperature, this caused the product slow oxidation rancidity. This explained why storage at $60^{\circ} \mathrm{C} \mathrm{PV}$ gradually increased comparing to storage at room temperature (Figure 4).

The TBA was another index of the lipid oxidation by measuring the level of aldehyde in the products. The red color as a result of the specific reaction of thiobarbituric acid and malonaldehyde can be measured at the absorbance of $532 \mathrm{~nm}$. The result of TBA value was increased in the same direction as found in the PV in Figure 5-7.

The TBA decreased to below $1 \mathrm{mg}$ malonadehyde / kg when $1.6 \mathrm{~g}$ / kg GSE product was added to the stored fried product for 6days. The result of low TBA values supported the effectiveness of GSE in inhibiting lipid oxidation. The result was similar to the report of addition the GSE to turkey and stored for 13 days at $4{ }^{\circ} \mathrm{C}$ that could decrease TBA values below $1 \mathrm{mg}$ malonadehyde / $\mathrm{kg}$ [1]. The result was comparable to that of other authors that the GSE could prevent lipid oxidation on cooked 
Citation: Vayupharp B, Laksanalamai V (2012) Recovery of Antioxidants from Grape Seeds and its Application in Fried Food. J Food Process Technol 3:152. doi:10.4172/2157-7110.1000152

Page 6 of 6

chicken. The TBA was increased to 13.93 malonadehyde / kg in the product without adding salt and GSE. When the GSE was added to the product at concentrations of 10 and $20 \mathrm{~g} / \mathrm{kg}$ product the TBA was decreased to 0.74 and 0.48 malonadehyde / kg, respectively [9]. Thus, it appeared that GSE could be more effective in inhibiting lipid oxidation at the higher concentration.

\section{Conclusion}

It was concluded that ethanol at the concentration of $50 \%$ was the most appropriate solvent for grape seed extraction in terms of cost of operation and safety concerns. The proper extraction condition was achieved by using $7.5 \mathrm{~g}$ of grape seeds at the extraction temperature of $50^{\circ} \mathrm{C}$ for 6 hours. By this condition, the extraction yield was $14.86 \%$ with the utmost antioxidant properties as determined by the $\mathrm{EC}_{50}$ and reducing power values equal to $214.6 \mu \mathrm{g} / \mathrm{ml}$ and 2.38 , respectively. The effect of the extract on retarding oxidative rancidity of fried pork products was compared with 2 commercial additives; BHT and gallic acid. At the concentration of 1.6 ( $\mathrm{g} / \mathrm{kg}$ product) the extract was similar in retarding rancidity efficiency to BHT but lower than gallic acid.

\section{References}

1. Mielink MB, Olsen E, Vogt G, Adeline D, Skrede G (2006) Grape seed extract as antioxidant in cook, cold store turkey. Meat LWT 39: 191-198.

2. Sanchez-Moreno C, Jose A, Larrauri Saura-Calixto F (1999) Free radical scavenging capacity and inhibition of lipid oxidation of lipid oxidation of wine, grape juices and related polyphenolic constituents. Food Res Int 32: 407-412.

3. Baydar NG, Özkan G, Yasar S (2007) Evaluation of the antiradical and antioxidant potential of grape extracts. Food Control 18: 1131-1136.

4. Garcia-Marino M, Rivas-Gonzalo JC, Ibanez E, Garcia-Moreno C (2006) Recovery of catechins and proanthocyanidins from winery by-products using subcritical water extraction. Anal Chim Acta 563: 44-50.

5. Nawaz H, Shi J, Mittal GS, Kakuda Y (2006) Extraction of polyphenols from grape seeds and concentration by ultrafiltration. Separation and Purification Technology 48: 176-181.

6. Shahidi F, Wanasundara PK (1992) Phenolic antioxidants. Crit Rev Food Sci Nutr 32: 67-103.

7. Lu Y, Foo YL (1999) The polyphenol constituents of grape pomace. Food Chem 65: 1-8.

8. Ahn J, Grun IU, Fernando LN (2002) Antioxidant properties of natural plant extracts containing polyphenolic compounds in cooked ground beef. J Food Sci 67: 1364-1369.

9. Lau DW, King J (2003) Pre- and Post-mortem use of grape seed extract in dark poultry meat to inhibit development of thiobarbituric acid reactive substances. $J$ Agric Food Chem 51: 1602-1607.

10. Katsube T, Tabata H, Ohta Y, Ymamasaki Y, Anuurad E, et al. (2004) Screening for antioxidant activity in edible plant products: Comparison of lowdensity lipoprotein oxidant assay, DPPH radical scavenging assay, and folinciocalteu assay. J Agric Food Chem 52: 2391-2396.

11. Jayaprakasha GK, Singh RP, Sakariah KK (2001) Antioxidant activity of grape seed (Vitis vinifera) extracts on peroxidation models in vitro. Food Chem 73: 285-290.

12. Miller DD (1998) A Laboratory. Manual Food Chemistry, John Wiley \& Son Inc. New York.

13. Allen JC, Hamilton RJ (1999) Rancidity in meats. Rancidity in Foods. (3 ${ }^{\text {rd }}$ edn) An Aspen Publication, Maryland.

14. A.O.A.C (1995) Official Methods of Analysis of the Association of AOAC international (16 $16^{\text {th }}$ Edn.) 2.

15. Krijgsman J (1992) Precipitation. Purification. Product Recovery in Bioprocess Technology. Butterworth Heinemann, United Kingdom.

16. Pekic B, Kovac V, Alonso E, Revilla E (1998) Study of the extraction of proanthocyanidins from grape seeds. Food Chem 61: 201-206.

17. Shi J, Yu J, Pohorly J, Young JC, Bryan M, et al. (2003) Optimization of the extraction of polyphenols from grape seed meal by aqueous ethanol solution. Food Agriculture \& Environment 1: 42-47. 